Cahiers $d u$ MONDE RUSSE

\section{Cahiers du monde russe}

Russie - Empire russe - Union soviétique et États indépendants

$58 / 4 \mid 2017$

Varia

\title{
Catherine Gousseff, Échanger les peuples : Le déplacement des minorités aux confins polono-soviétiques (1944-1947)
}

\section{Mayhill C. Fowler}

\section{(2) OpenEdition}

1 Journals

\section{Electronic version}

URL: http://journals.openedition.org/monderusse/10169

DOI: 10.4000/monderusse.10169

ISSN: $1777-5388$

\section{Publisher}

Éditions de l'EHESS

\section{Printed version}

Date of publication: 1 October 2017

Number of pages: $714-718$

ISBN: 978-2-7132-2698-4

ISSN: $1252-6576$

\section{Electronic reference}

Mayhill C. Fowler, "Catherine Gousseff, Échanger les peuples : Le déplacement des minorités aux confins polono-soviétiques (1944-1947)", Cahiers du monde russe [Online], 58/4 | 2017, Online since 01 October 2017, connection on 06 January 2021. URL: http://journals.openedition.org/monderusse/ 10169 ; DOI: https://doi.org/10.4000/monderusse.10169 
Catherine GOUSSEFF

Échanger les peuples

Le déplacement des minorités aux confins polono-soviétiques (1944-1947)

Paris : Fayard, 2015, 414 p.

Transfer. Exchange. Expulsion. Evacuation. Repatriation. Migration. Each word describes the movement of peoples variously, suggesting difference in agency (voluntary or involuntary) and direction (whether to or from home). Catherine Gousseff's magisterial book includes all these multiple ways of leaving and arriving, and shows how such movement was always painful, even behind the front lines of war. About 30 million people moved - through transfer, expulsion, or migration-between 1944 to the end of the decade. Gousseff focuses on the two million classified as Poles and Ukrainians and argues that the "exchange" of these 
populations, moving Poles to Poland and Ukrainians to Soviet Ukraine, created the border between Poland and the Soviet Union. In short, the violent organization of people created the border, as much as the border determined the organization of people.

Gousseff employs a focused chronological and geographic specificity; her book centers on 1944-1947 and explains the emergence of the border between Poland and Soviet Ukraine. She begins her story in September 1944, with the signing of a bilateral agreement between the Soviet Union and the "Lublin Poles," the Polish Committee of National Liberation. In other words, Stalin went ahead and decided to begin organizing the border with the Communist Poles eager to work with the Soviet Union before they were recognized as the leaders of Poland. While she references the Volyn massacres of 1943, when Ukrainian nationalists massacred Poles, she does not include this ethnic violence as part of the story of border creation. Yet she ends the story not in 1946, when the Soviet Union officially considered the exchanges complete and attempted to close the border, but in April 1947 with the Akcja Wisla, when Poles violently forced Ukrainians to resettle. The Akcja Wisla, then, becomes a formative factor in border creation; Volyn 1943 part of the war writ large. The choice signals her geographic focus as well; the book traces, piece by piece, the emergence of a state border between socialist Poland and Soviet Ukraine, and the attempt on the part of agents at all levels to make ethnic borders in this still multi-ethnic region match Stalin's new political borders.

The challenge of tracing the emergence of this border and its consequences lies in the balance between the macro and the micro-level, and this book illustrates the costs and benefits of a deep micro-level approach. Gousseff's book should become the go-to volume on the years 1944-1947 on the border between Poland and Ukraine. She moves methodically from the Bug/Buh river in Volyn south to the San River in Galicia and the southern Carpathians, tracing the shifting reactions of Poles and Ukrainians in each location, and explaining precisely who did what to whom, that is, the details of population exchange. The chaotic and complex task of moving two million people emerges with sharp detail from the pages of this book.

But the sharp focus leaves some of the macro-level context out of the picture. For example, there was no fully internationally-recognized Polish leadership in 1944; September 1944 is still well before Yalta, the end of the war in Europe, or Potsdam. There were two candidates for ruling Poland: the Communists working with Stalin in Moscow, and the non-Communist government in exile in London. The Warsaw Uprising, which began 1 August 1944 by the Armia Krajowa, the Polish Home Army working with the non-Communist Poles in London, surely affected the urgency of the Lublin Poles to make any deal with Stalin that they could. In other words, while Khrushchev was orchestrating the removal of Poles from Volyn and attempting to annex part of Poland (Holmshchyna) to Soviet Ukraine, the war was not even over and the future of Poland was far from certain. How much of this border creation was not only an attempt to match ethnic with political borders, but also to prove to the international community that the Soviet Union should have 
Poland in its sphere? The larger Polish history fades into the background with the focus on its border with the Soviet Union.

The Soviet Ukraine story fades into the background as well. In these years, and well into the 1950s, the Ukrainian nationalists were more than a thorn in the Soviet side. Finally conquering the Ukrainian nationalists was one of Khrushchev'sand Stalin's - major goals and challenges. Excluding the Ukrainian nationalists' attempts to rid the territory of Poles from the story, except as background, makes perfect sense for Gousseff's argument. But the Ukrainian nationalists played a major role, as she rightly notes, in the contestation of the border around the San River. The role of the Ukrainian nationalists, and their desire for an independent and ethnically homogenous Ukrainian state, falls into the background perhaps more than it should.

Finally, Gousseff's move to place the Akcja Wisla as part of population transfers is a bold one. She argues that a crucial role in the movement of populations was the regulations surrounding the Soviet border zone. According to Soviet policy-and practice - there had to be an unpopulated perimeter around the border. By March 1947, however, there were 12,000 people living in these forbidden zones; people were also crossing back into Poland to claim property, or simply return home after tasting life in the USSR (p. 318). It was chaos. The Soviet Ukrainian authorities had to remove all the people living on the border, and they turned to local Polish army units to help removing people-Ukrainians - from the border. She therefore places the anti-Ukrainian hatred of the operation in the context of the larger story of resettling, transferring, and deporting this population. Yet I wonder if focusing so much on this frame of population transfer and exchange overly minimizes the causal factor of ethnic violence and retribution; the anti-Ukrainian hatred was connected to the anti-Polish violence of four years earlier. Still, the attempt to re-frame the Akcja Wisla is surely a welcome provocation.

Overall I think Gousseff shows the benefit of a deep micro-study. Her painstaking tracking of how this border emerges shows its contingency and allows her to reveal how very fluid ethnicity could be as a category, and the importance of local factors in large-scale state processes. Take the example of the Ukrainians in Polish territory. According to the agreement, they should be transferred to Soviet Ukraine. Fearful of Polish violence, they left without much coercion. Yet when they arrived "home," they were not welcomed by their co-ethnics. Rather, they were despised as zabužany, people unwelcome from the other side of the river. The Bug River divided people more than ethnicity. Why? The river had separated the Russian Empire from pre-partition Poland, the Soviet Union from independent Poland. Historical memory mattered more than nationality. "Ukrainian" was then a meaningful classification in policy, but less meaningful in practice than older belongings. These older belongings might signify wealth or class (the collectivized villagers' assumption that anyone living in Poland was necessarily richer), as well as experience (after all, the Ukrainians in Volyn were Soviet subjects and had been for twenty years). In short, Ukrainians from Poland did not belong with Ukrainians in Soviet Ukraine. This detailed tracking of the zabužany shows the extent to which 
nationality was a construction. This case also suggests that there was, by this point, a Soviet identity more weighty than nationality. To me, this raises the question of the UPA, the Ukrainian Insurgent Army, and its inclusion of "Ukrainians": could someone who had lived in Poland be Ukrainian? Could someone who had lived in the Soviet Union be "Ukrainian"? In other words, the example demonstrates how variously state and local actors interpreted "Ukrainian."

The micro-study also affords Gousseff the ability to show how the Soviet Union's system of population exchange was not systematic (p. 331). On the surface, that hardly seems true. After all, as she states, deportation was a practice well-honed by the USSR in the pre-war period. Yet actually organizing and relocating peoples happened differently in Volyn and Galicia, and differently in the case of organizing the border with Belarus and with Lithuania (where very few Poles, in fact, were allowed to or wanted to leave). One macro-narrative cannot possibly capture the nuances of the story for all the various groups of peoples on the Bug and San Rivers.

One reason for the lack of systematization was contingency. For example, Gousseff offers the example of the Rusyn people, a minority living among a minority, the Lemko people in the Carpathian mountains. Because the Rusyn were Orthodox (as opposed to Catholic or Greek Catholic), the Soviet Ukrainians deemed them "Ukrainian" enough to join Ukrainians in Soviet Ukraine. The Rusyns were the rare group, then, that wanted to leave, and they attempted to do so in spring 1945. Yet at this time Soviet resources could hardly be diverted to transfer an obscure people out of the Carpathians. And the Rusyns lived far from any railway lines and required carts and carriages to move themselves and their belongings across the border. So the transfer was a failure not because of a geo-political reason, but because of the very local contingent factor of spring rains, a deficit of carts, and no local railway line.

Further demonstrating both the fluidity of ethnicity as a category and the importance of local contingency is the case of the Lemkos themselves. Interestingly, Gousseff rarely uses the word "identity" to explain how people described themselves; she does so in only one case: the Lemkos, who understood themselves as Lemkos, not as Poles or Ukrainians (or any other group). In all other cases, Gousseff is careful to use "identity" as a term that people use to categorize, sort, and classify various groups. The Lemkos were deemed not Polish enough by the Poles, and not Ukrainian enough by the Soviet Ukrainians. Trapped in the border zone scheduled for de-population, they were then a prime target for the anti-Ukrainian action of the Akcja Wisla. They did not self-identify as Ukrainians, but were identified as such, in other words. Because the border was technically closed in 1946, the Lemkos and those surviving went not to the Soviet Union, but west, to the new regions acquired from Germany.

This is a book without heroes. No brave Warsaw Uprising fighters, no followers of Shuhevych fighting for a Ukrainian state, no one, on any side, saving anyone from violence. In an English, Polish, or Ukrainian translation, the book will create a stir. While not ignoring Stalin and Hitler as models of how to engage in mass violence, Gousseff focuses on the local contingencies shaping such violence. Her insistence 
on identity as a weapon used by states and actors to classify and organize people does not allow for any primordial national belonging. Borders are constructed and contingent, and created not by state officials in Potsdam and Yalta and Moscow, but by the violent expulsion and removal of people from their homes.

On a contemporary note, her book reads as remarkably prescient for the current situation in Ukraine. While the border with Poland is today uncontested, Ukrainians may still remember grandparents condemned as zabuzhany by their fellow villagers. Moreover, war is reshaping Ukraine's eastern border. Are Ukrainians who stay in the separatist region still Ukrainians? How will national, civic, and regional belongings shape the future Ukrainian society? Gousseff's story offers a cautionary tale, and suggests that the emerging border between Ukraine and the separatist regions will have long-term costs.

Mayhill C. Fowler

Stetson University 